\title{
Effect of Dietary Magnesium on Post Mortem Phosphocreatine Utilization in Skeletal Muscle of Swine: A Non-Invasive Study Using ${ }^{31}$ P-NMR Spectroscopy
}

\author{
By B. Moesgaard, I. Errebo Larsen, B. Quistorff, I. Therkelsen, V. Grøsfjeld Christensen and \\ P. Fogd Jørgensen
}

Department of Anatomy and Physiology, The Royal Veterinary and Agricultural University, Copenhagen, Denmark and the NMR Centre, University of Copenhagen, Denmark.

\begin{abstract}
Moesgaard, B., I. Errebo Larsen, B. Quistorff, I. Therkelsen, V. Grøsfjeld Christensen and P. Fogd Jørgensen. Effect of dietary magnesium on post mortem phosphocreatine utilization in skeletal muscle of swine. A non-invasive study using ${ }^{31}$ P-NMR Spectroscopy. Acta vet. scand. 1993, 34, 397-404. - The effect of dietary magnesium on the post mortem $\mathrm{PCr}$ (phosphocreatine) decay in muscle of heterozygote malignant hyperthermia pigs was studied after in vivo exposure to a combination of halothane and succinylcholine. The pigs were anaesthetized with halothane and succinylcholine was injected in the ear vein. Immediately after initiation of the depolarizing neuromuscular blocking effect of succinylcholine the animals were captive-bolt stunned. The $\mathrm{PCr}$ decay, reflecting ATP turnover, was followed in situ by ${ }^{31} \mathrm{P}-\mathrm{NMR}$ spectroscopy in the biceps femoris muscle for the subsequent $40-70 \mathrm{~min}$ post mortem. In 3 of the 4 experiments, the $\mathrm{Mg}$-fed pig had a significantly reduced rate of $\mathrm{PCr}$ hydrolysis compared to the control animal. The mechanism of this magnesium effect is unknown.
\end{abstract}

hyperthermia; heterozygote; pigs; $\mathrm{Mg}^{2+}$; halothane; succinylcholine; glycolysis.

\section{Introduction}

Heterozygote malignant hyperthermia (MH) pigs are phenotypical intermediates between normal and homozygote MH-pigs, with respect to the function of the ryanodine binding $\mathrm{Ca}^{2+}$-channel protein in the sarcoplasmic reticulum (Mickelson et al. 1989, Knudson et al. 1990).

The condition PSE (pale, soft and exudative) meat is not only present in the homozygote MH-pigs (n/n), but also to a significant extent in the heterozygotes (Webb et al. 1987, Jensen \& Barton-Gade 1985). While heterozygote MH-pigs are not halothane susceptible, a combination of halothane and succinylcholine will provoke $\mathrm{MH}$-symptoms in these pigs
(Moesgaard et al. 1994).

Supply of dietary magnesium can influence stress-susceptibility and PSE development in pigs (Classen 1990, Jørgensen 1989a). Intravenous injection of magnesium sulphate prior to exsanguination produced an increased initial ratio of phosphocreatine (PCr) to total creatine level and retarded the post mortem decrease of adenosine triphosphate (ATP) and $\mathrm{PCr}$ as well as lactate increase in different breeds of stress-susceptible pigs (Sair et al. 1970, Lister \& Ratcliff 1971). We recently observed that the rate of $\mathrm{PCr}$ decay and glycolysis was 4-5 fold higher in malignant hyperthermia heterozygote pigs than in normal animals 
after stimulation with halothane/succinylcholine (Moesgaard et al. 1994). To clarify whether dietary Mg-supply affects this accelerated post mortem PCr consumption, 8 heterozygote pigs $(\mathrm{Nn})$ with respect to the Hal locus were investigated by pair-feeding with/without supplementation of magnesium. The results showed a significantly reduced rate of $\mathrm{PCr}$ decay post mortem in the $\mathrm{Mg}$-fed compared to the control animals.

\section{Materials and methods}

Animals

Six male and 2 female Danish Landrace pigs, age $8 \frac{1}{2}-11 \frac{1}{2}$ weeks, weight $17-30 \mathrm{~kg}$, were used. All animals were halothane negative heterozygotes, with respect to the malignant hyperthermia $(\mathrm{MH})\left(\mathrm{Hal}^{\mathrm{N}} / \mathrm{Hal}^{\mathrm{n}}\right)$ gene, according to their pedigree and to their genotypes of closely linked loci $\left(\mathrm{H}^{\mathrm{a}} / \mathrm{H}^{-}, \mathrm{Phi}^{\mathrm{A}} / \mathrm{Phi}^{\mathrm{B}}, J \phi r\right.$ gensen 1981).

The animals were ad libitum fed a standard feed-mixture with an estimated magnesium content of $1.4 \mathrm{~g}$ per kg dry matter. The last 3 days before the NMR-experiment 4 pigs were given $20 \mathrm{~g}$ light magnesium carbonate (containing approximately $40-45 \% \mathrm{MgO}$ ) per $\mathrm{kg}$ feed-mixture, in order to raise magnesium content to a value of $6.2 \mathrm{~g}$ per $\mathrm{kg}$ dry matter. The duration of extra magnesium supply was estimated on the basis of previous investigations on the kinetics of plasma $\mathrm{Mg}$ (Jørgensen 1989a). The time constant (k) for plasma Mgincrease was $0.67 \pm 0.23$ day $^{-1}( \pm$ SEM, $5 \mathrm{df}$ ) corresponding to a half-time of approximately $24 \mathrm{~h}$. The pigs were handled in pairs where 1 from each of the 4 pairs received the magnesium enriched food.

On the day of the NMR-experiment the pigs were transported to the NMR centre, anaesthetized for $1 / 2-1 \frac{1}{2} \mathrm{~h}$ with halothane/oxygen supplied via a face mask, applying $5 \%$ halothane initially decreasing to $2 \%$ after a few minutes. A blood sample was taken just before the succinylcholine injection. Succinylcholine $(1.5 \mathrm{ml}, 50 \mathrm{mg} / \mathrm{ml})$ was injected intravenously in an earvein and 30-60 sec after the initiation of the induced depolarizing neuromuscular blocking effect could be observed, the animals were captive-bolt stunned, resulting in cardiac arrest within $1 \mathrm{~min}$. The post mortem ATP turnover, as reflected in the rate of decrease of PCr was followed for 40-70 min. Throughout the experiment, the temperature was followed in the biceps femoris muscle 3-4 $\mathrm{cm}$ below the surface with a needle thermometer in all animals except one.

\section{Blood samples}

Heparinized blood samples were collected after feeding in the morning. One additional sample was collected at the NMR centre immediately before administration of succinylcholine. The samples were analyzed with respect to acid-base balance on a blood-gas analyzer in order to ensure proper anaesthesia, and the level of the electrolytes $\mathrm{K}^{+}$and $\mathrm{Ca}^{2+}$ was determined with ion selective electrodes. Plasma was separated and kept at $-20^{\circ} \mathrm{C}$ until analyzed for total $\mathrm{Ca}$ and $\mathrm{Mg}$ (atomic absorption spectrophotometry).

\section{Biochemical analysis of biopsies}

One surgical biopsy was obtained from the right biceps femoris muscle from each pig, immediately before the administration of succinylcholine. The freeze-clamped biopsies (Quistorff \& Poulsen 1980) were kept in liquid nitrogen, and later stored at $-80^{\circ} \mathrm{C}$ until analyzed. The biopsies were extracted in perchloric acid (Lamprecht \& Trautschold 1974) and the neutralized extracts were analyzed by standard enzymatic assays for PCr and ATP (Lamprecht et al. 1974), $\mathrm{P}_{1}$ (Gawehn 1974) and lactate (Hohorst 1970). Results are expressed as $\mu$ moles/g of wet weight. 
Table 1. Physiological parameters of the groups of heteroxygote malignant hyperthermia pigs involved in the study. Temperature and plasma electrolyte concentration were recorded during halothane anaesthesia immediately prior to the succinylcholine stimulation.

\begin{tabular}{|c|c|c|c|c|c|c|c|}
\hline Pig no. & $\begin{array}{c}\text { Mg } \\
\text { supply }\end{array}$ & $\begin{array}{c}\text { Age } \\
\text { (weeks) }\end{array}$ & $\begin{array}{c}\text { Werght } \\
\text { (kg) }\end{array}$ & $\begin{array}{c}\mathrm{T}_{0} \\
\left({ }^{\circ} \mathrm{C}\right)\end{array}$ & $\begin{array}{l}\text { Calcium } \\
\text { Ion } \\
(\mathrm{mmol} / \mathrm{l})\end{array}$ & $\begin{array}{l}\text { Calcium } \\
\text { (total) } \\
(\mathrm{mmol} / \mathrm{l})\end{array}$ & $\begin{array}{c}\text { Magnesium } \\
\text { (total) } \\
(\mathrm{mmol} / \mathrm{l})\end{array}$ \\
\hline 152 & + & $11 \frac{1}{2}$ & 24 & 37.5 & 1.54 & 2.54 & 1.63 \\
\hline 153 & - & $11 \frac{1}{2}$ & 25 & 39.4 & 1.48 & 2.31 & 1.28 \\
\hline 156 & + & 11 & 28 & - & 1.55 & 237 & 1.28 \\
\hline 157 & - & 11 & 30 & $41^{*}$ & 1.41 & 2.39 & 1.20 \\
\hline 110_2 & + & $81 / 2$ & 18 & 37.5 & 1.38 & 2.55 & 1.76 \\
\hline 110_13 & - & $81 / 2$ & 17 & 38.0 & 1.32 & 1.95 & 1.15 \\
\hline 110_6 & + & $81 / 2$ & 21 & 38.4 & 1.32 & 2.19 & 1.54 \\
\hline 110_3 & - & $8^{1 / 2}$ & 19 & 39.0 & 1.23 & 2.23 & 1.16 \\
\hline Average & + & & & 37.8 & 1.45 & 2.41 & $1.55^{\mathrm{b}}$ \\
\hline value $\pm \mathrm{SD}$ & & & & \pm 0.5 & \pm 0.12 & \pm 0.17 & \pm 0.20 \\
\hline Average & - & & & 39.4 & 1.36 & 2.22 & 1.20 \\
\hline value $\pm \mathrm{SD}$ & & & & \pm 1.2 & \pm 0.11 & \pm 0.19 & \pm 0.06 \\
\hline
\end{tabular}

*) The initial temperature of pig no 157 is extrapolated to tıme zero b $\mathrm{P}<0.05$ for $\mathrm{Mg}$-fed versus control anımals

\section{NMR measurements}

The anaesthetized pigs were fixed on their right sides in a cradle, as described by Moesgaard et al. 1994. A flexible wooden plate was fixed over the thigh of the 2 largest animals, to ensure that the muscle remained in the isocenter of the magnet. This resulted in some compression of the thigh, but control ${ }^{31} \mathrm{P}$ NMR spectrum did not indicate an increased $\mathrm{P}_{1} / \mathrm{PCr}$ ratio, as would have been expected if significant hypoxia had been caused (Quistorff et al. 1993).

The ${ }^{31} \mathrm{P}-\mathrm{NMR}$ experiments were performed with a wide-bore $(31 \mathrm{~cm}$ diameter) 4.7 Tesla Magnex magnet interfaced to an Otsuka Electronics Vivospec ${ }^{\mathrm{R}}$ Spectrometer. NMR signals were collected from the lateral side of the left biceps femoris muscle applying an inductively driven, 2-turn surface coil $(3.8 \mathrm{~cm}$ diameter), tuned to the resonance frequency of phosphorous, $81.02 \mathrm{Mhz}$. Pulse width was 100 $\mu$ seconds, corresponding to a $180^{\circ}$ pulse in the centre of the loaded coil. Each spectrum was the sum of 64 FID's collected with an interpulse delay of $5 \mathrm{sec}$. One control spectrum was acquired prior to the injection of succinylcholine and spectra were acquired continuously post mortem for about 40-70 min until the disappearance of $\mathrm{PCr}$. The resonances were fitted to a Lorentzian line shape using a least square method. From the chemical shift difference between inorganic phosphate and $\mathrm{PCr}, \mathrm{pH}$ was calculated according to Taylor et al. (1983).

\section{Results}

\section{Blood samples}

Plasma magnesium concentration in the morning blood samples was increased in the Mg-fed compared to the control animals (data not shown). In the blood samples collected immediately before succinylcholine injection the level of total magnesium was some $30 \%$ higher in the Mg-fed compared to the control 
Table 2. Analytical biochemical and NMR measurements in $m$. biceps femoris from anaesthetized heteroygote malignant hyperthermia pigs.

\begin{tabular}{|c|c|c|c|c|c|c|c|c|c|}
\hline \multirow[b]{2}{*}{ Pig no. } & \multirow[b]{2}{*}{$\begin{array}{l}\mathrm{Mg} \\
\text { supply }\end{array}$} & \multicolumn{3}{|c|}{ Biochemistry } & \multicolumn{5}{|c|}{ NMR } \\
\hline & & $\mathrm{PCr}_{0} / \mathrm{ATP}_{0}$ & $\mathrm{Pi}_{0} / \mathrm{ATP}_{0}$ & $\begin{array}{l}\text { Lactate }_{0} \\
(\mu \mathrm{mol} / \mathrm{g})\end{array}$ & $\mathrm{PCr}_{0} / \mathrm{ATP}_{0}$ & $\mathrm{P}_{0} / \mathrm{ATP}_{0}$ & $\begin{array}{c}\mathrm{t}_{1 / 2} \\
\text { (PCr decay) } \\
\text { (min.) }\end{array}$ & $\mathrm{pH}_{0}$ & $\begin{array}{l}\mathrm{pH} \text { declıne } \\
\left(\mathrm{x} 10^{2} \mathrm{pH}\right. \\
\text { units/mın. })\end{array}$ \\
\hline 152 & + & 3.0 & 1.3 & 7.8 & 2.7 & 0.4 & $15.4^{c} \pm 1.0$ & 6.98 & $1.4^{\mathfrak{c}} \pm 0.1$ \\
\hline 153 & - & 3.1 & 1.1 & 7.0 & 3.0 & - & $9.6 \pm 0.6$ & 7.08 & $2.9 \pm 0.5$ \\
\hline 156 & + & 2.8 & 1.1 & 10.9 & 4.3 & 0.8 & $8.1^{b} \pm 0.8$ & 7.39 & $1.8^{c} \pm 0.3$ \\
\hline 157 & - & 2.8 & 1.4 & 11.0 & 3.0 & 1.0 & $3.1 \pm 1.1$ & 7.10 & $7.9 \pm 2.0$ \\
\hline 110_2 & + & 2.8 & 1.2 & 6.4 & - & - & $17.5 \pm 1.8$ & - & $2.1^{c} \pm 0.3$ \\
\hline 110_13 & - & 2.9 & 1.5 & 4.9 & 3.2 & 0.4 & $15.6 \pm 0.9$ & 6.82 & $0.69 \pm 0.05$ \\
\hline 110_6 & + & 2.6 & 1.0 & 12.0 & 4.0 & 0.4 & $11.6^{\mathrm{a}} \pm 0.4$ & 7.05 & $2.9^{a} \pm 0.3$ \\
\hline $110 \_3$ & - & 2.6 & 1.3 & 8.6 & 3.9 & 0.2 & $9.0 \pm 0.9$ & 6.97 & $2.0 \pm 0.2$ \\
\hline $\begin{array}{l}\text { Average } \\
\text { value } \pm S D\end{array}$ & ${ }^{+}$ & $2.8 \pm 0.2$ & $1.2 \pm 0.1$ & $9.3 \pm 2.6$ & $3.7 \pm 0.9$ & $0.5 \pm 0.2$ & $13.2 \pm 4.2$ & $7.14 \pm 0.22$ & $2.1 \pm 0.6$ \\
\hline $\begin{array}{l}\text { Average } \\
\text { value } \pm \mathrm{SD}\end{array}$ & $D^{-}$ & $2.9 \pm 0.2$ & $1.3 \pm 0.2$ & $7.9 \pm 2.6$ & $3.3 \pm 0.4$ & $0.5 \pm 0.4$ & $9.3 \pm 5.1$ & $6.99 \pm 0.13$ & $3.4 \pm 3.2$ \\
\hline
\end{tabular}

a: $\mathrm{P}<0.1, \mathrm{~b}: \mathrm{P}<0.05$ and c. $\mathrm{P}<0.01$ for $\mathrm{Mg}$-fed versus control anımals.

animals (see Table 1), while total calcium and $\mathrm{K}^{+}$was not different. Free calcium, however, was slightly higher $(7-10 \%)$ in the magnesium-fed animals.

\section{Temperature}

The initial temperatures ranged from 37.5 to $41^{\circ} \mathrm{C}$ (Table 1 ), with the control animals having slightly higher initial temperatures, when compared to the Mg-fed animal of the same pair.

\section{Biochemical analysis of biopsies at rest}

Due to the relatively low $\mathrm{S} / \mathrm{N}$ ratio of the NMR experiments, comparison between animals are best performed by comparing metabolite ratios, rather than absolute values of individual metabolites. The $\mathrm{P}_{1} / \mathrm{ATP}$ and $\mathrm{PCr} / \mathrm{ATP}$ ratios at rest prior to the initiation of the halothane/succinylcholine stimulation were the same in the 2 groups as was the level of lactate (see Table 2).

\section{NMR-measurements}

The time courses of the post mortem PCr decay were fitted to a mono-exponentional function (Moesgaard et al. 1994) with the measurement in the control spectra taken as $100 \%$. As shown in Table 2, there was a significantly slower PCr decay in 3 of the $4 \mathrm{Mg}$-fed pigs, with rate constants reduced by $1.3-2.5$ fold, when compared to the control animals. Concerning the experiment with the 2 smallest pigs, there was no significant difference between the rates of $\mathrm{PCr}$ decay.

Initial intracellular $\mathrm{pH}\left(\mathrm{pH}_{0}\right)$ and the rate of $\mathrm{pH}$ decline (in $m$. biceps femoris) is also shown in Table 2. After an initial increase, $\mathrm{pH}$ decreased linearly. The $\mathrm{H}^{+}$accumulation in $m$. biceps femoris of pigs no. 152-157 was significantly slower in the Mg-fed animals compared to the controls while the opposite was observed in pigs no. 110_2, 13, 6, 3. Initial pH was $7.0-7.1$ in 5 of the pigs, while $\mathrm{pH}_{0}$ was extremely low (6.8) in pig no. 110_13 and ex- 
Table 3. Chemical shift difference between $\alpha$-ATP and B-ATP peaks of heterozygote malignant hyperthermia susceptible pigs at rest.

\begin{tabular}{|c|c|c|c|}
\hline & $\begin{array}{l}\text { Linewidth } \\
\alpha \text {-ATP }\end{array}$ & $\begin{array}{c} \pm \text { SD (Hz) } \\
\text { B-ATP }\end{array}$ & $\begin{array}{l}\text { Chemical shift difference } \\
(\alpha-\mathrm{ATP}-\beta-\mathrm{ATP}) \\
(\mathrm{Hz})( \pm \mathrm{SD})\end{array}$ \\
\hline $\begin{array}{l}+\mathrm{Mg} \\
-\mathrm{Mg}\end{array}$ & $\begin{array}{l}53 \pm 13 \\
73 \pm 7\end{array}$ & $\begin{array}{l}55 \pm 19 \\
67 \pm 5\end{array}$ & $\begin{array}{l}689 \pm 9 \\
695 \pm 4\end{array}$ \\
\hline
\end{tabular}

tremely high (7.4) in pig no. 156.

Intracellular $\mathrm{Mg}^{2+}$ concentrations may be calculated from the chemical shift differences between the resonances of $\alpha$ - and B-ATP appropriately corrected for $\mathrm{pH}$. (Gupta et al. 1978). As it appears from Table 3 we did not observe significant differences in the $\alpha-\beta$-ATP chemical shift between the 2 groups. Thus intracellular free magnesium is not affected by the moderate but significant incrase of total plasma magnesium caused by the magnesium feeding.

\section{Discussion}

Magnesium supply resulted in a significantly lower $\mathrm{t}_{1 / 2}$ value for PCr decay in $\mathrm{m}$. biceps femoris as well as a slower decline of intracellular $\mathrm{pH}$, in 3 of the 4 experiments reflecting a reduced ATP turnover. A significant differerence between the experiments was, however, also present.

The most pronounced reaction to the halothane/succinylcholine challenge was observed in the 4 oldest and largest pigs indicating a dependency of the reaction on the age/weight of the pigs. This is in agreement with Webb (1981) who found that the barn-yard halothane test should not be performed on animals younger than 8 weeks and that breed differences were present with respect to the age at which maximum expression was reached. Furthermore Fay \& Gallant (1990) has observed an incomplete expression of $\mathrm{MH}$ in muscle biopsies from young susceptible pigs, probably caused by a reduced myoplasmic calcium release on exposure to triggering agents or to decreased sensitivity to calcium in the muscle cells. The skeletal muscles must consequently be of a certain maturity in order to express halothane susceptibility (Jørgensen $1989 \mathrm{~b})$. This age and weight effect is also present in the smallest pigs of the present investigation as they were relatively unaffected of the stress induced by halothane/succinylcholine.

Free plasma calcium (but not total) was also affected by the magnesium-supply. The higher level of calcium ions observed in the magnesium-fed pigs could be a secondary effect to the increased magnesium concentration, since magnesium ions may replace some of the protein bound calcium ions (Table 1). Although the $\mathrm{Mg}$ in the plasma compartment accounts for only about $1 \%$ of the total body content of magnesium (Reinhart 1988), the higher plasma concentration of the Mg-fed pigs indicates that these pigs could have build up larger mobilisable magnesium-stores than the controls. The labile Mg-pools are primarily contained in connective tissue, skin and the soft tissues of the abdominal cavity (Reinhart 1988). Magnesium is essential for the synthesis and function of ATP in numerous enzymatic reactions. Within the cell magnesium is mainly complex bound to ATP and other organic compounds leaving only a fraction of total magnesium left as $\mathrm{Mg}^{2+}$. In some tissues e.g. skeletal tissue intracellular magnesium reflects the dietary magnesium supply (Classen et al. 1987). In the present investigation $\mathrm{Mg}$ supply apparently did not influence intracellular $\mathrm{Mg}^{2+}$ concentration. This could be due to a relatively short period of magnesium supply. On the other hand in a previous investigation 8 days of magnesium supply did not change the concentration of total magnesium in liver, 


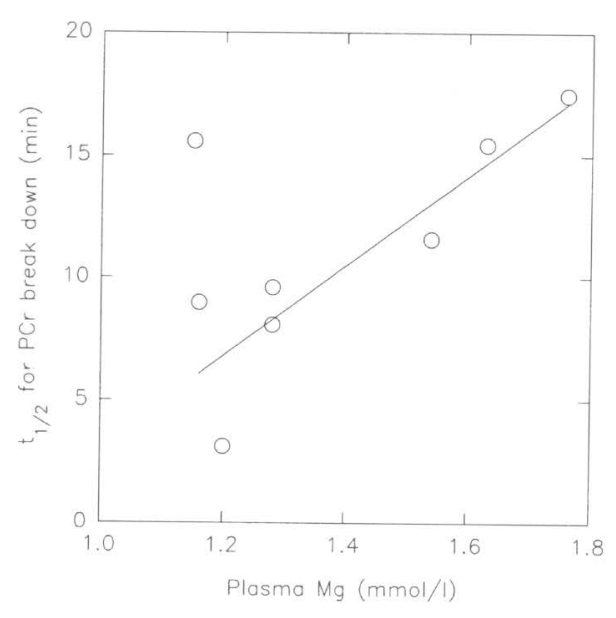

Figure 1. Relationshıp between post mortem break down $\left(\mathrm{t}_{1 / 2}, \mathrm{~min}\right)$ of phospho-creatine (PCr) in $m$ biceps femorls measured by ${ }^{31} \mathrm{P}-\mathrm{NMR}$ spectroscopy and plasma magnesium immediately before succinylcholine stimulation Data from eight heterozygote $(\mathrm{Nn})$ malıgnant hyperthermia susceptible Danish Landrace pigs.

kidney, heart and skeletal muscles (Jørgensen 1989a). The dynamics of magnesium exchange into tissues remains consequently somewhat controversial.

As shown in Fig. 1 a linear relationship between plasma magnesium and the rate of PCr breakdown seems to be present. This is, however, likely to hold true only within a narrow magnesium concentration range. Neither low plasma magnesium levels (increased excitability of the central nervous system and of the skeletal muscles (Classen 1990)) nor extremely high levels of plasma magnesium (curarization of the skeletal muscles (Sair et al 1970)) are desirable. We suggest that there may be an optimal plasma level of extracellular magnesium, with respect to its ability to reduce the halothane/succinylcholine accelerated ATP turnover in skeletal muscles of heterozygote animals. This level may be ex-

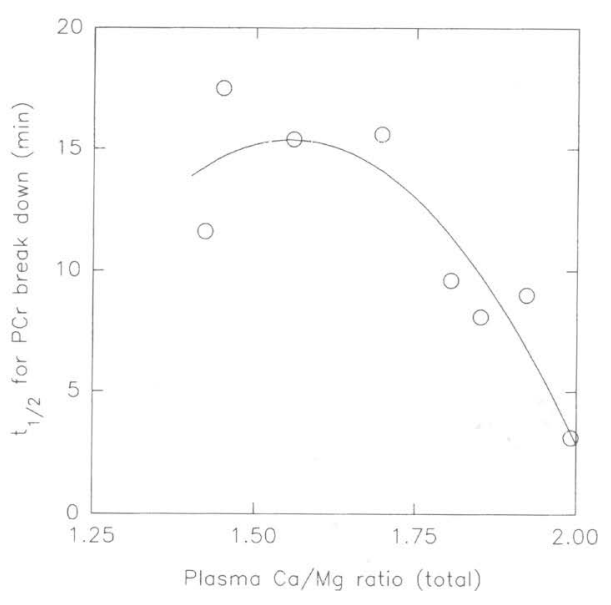

Figure 2. Relationship between post mortem break down $\left(\mathrm{t}_{1 / 2}, \mathrm{~min}\right)$ of phosphocreatine (PCr) in $m$. biceps femorls measured by ${ }^{31} \mathrm{P}-\mathrm{NMR}$ spectroscopy and the ratio of plasma calcium/magnesium (total) immediately before succinylcholine stımulation. Data from 8 heterozygote $(\mathrm{Nn})$ malignant hyperthermia susceptible Danısh Landrace pigs.

pected to be influenced by the calcium concentration with a certain ratio of plasma calcium/magnesium as the optimum. Fig. 2 shows $\mathrm{t}_{1 / 2}$ for the PCr decay versus the ratio of plasma $\mathrm{Ca}_{\text {total }} / \mathrm{Mg}_{\text {total }}$, as measured in the blood sample immediately before administration of succinylcholine. By fitting the data to a 2 nd order polynomium it appears that in this study the ratio is optimal at a value of 1.55.

In a separate investigation (Moesgaard et al. 1994) ${ }^{31} \mathrm{P}-\mathrm{NMR}$ spectroscopy of $m$. biceps femoris in situ was compared with analytical biochemical analysis of muscle biopsies with respect to the rate of ATP and PCr break down and lactate accumulation. A high rate of ATP and PCr break down was accompanied by a correspondingly high rate of lactate accumulation and decline in $\mathrm{pH}$. Consequently the results of the present investigation indicate that the rate of glycolysis as well as the rate of 
ATP and PCr break down is reduced in $\mathrm{Mg}$ supplied animals.

\section{Conclusion}

The present investigation clearly shows that a $30-50 \%$ increase of extracellular total magnesium considerably slows down PCr decay and intracellular $\mathrm{H}^{+}$accumulation in heterozygote MH pigs, confirming previous observations on stress-susceptibility (Jørgensen 1989a). The effect of magnesium may depend upon the maturity of the muscle and may interact with extracellular calcium also, but the basic mechanism of the magnesium effect remains unknown.

\section{Acknowledgements}

We are grateful for the support from The Food Research Programme under the Danish Ministry of Agriculture, The Danish Medical Research Council (12-6281) and The Velux (1981) Foundation.

\section{References}

Classen $H G$. Systemic stress and the role of magnesium. Metal ions in B1ol. Systems, 1990, 26, 321339.

Classen HG, Fischer G, Marx J, Schimatschek H, Schmid C, Stein C: Prevention of stress-induced damage in experimental animals and livestock by monomagnesium-1-aspartate hydrochloride. Magnesium, 1987, 6, 34-39.

Fay RS, Gallant EM: Halothane sensitivity of young pigs in vivo and in vitro. Amer. J. Physiol., 1990, 259, R133-R138.

Gawehn K: Inorganic Phosphate. UV-Spectrophotometric Method. In: Bergmeyer HU (ed.): Methods of Enzymatic Analysis 1974, 4, 2234-2238.

Gupta RK, Jeffrey LB, Rose ZB: The determination of the free magnesium level in the human red blood cell by ${ }^{31}$ P NMR. J. Biol. Chem., 1978, 253, 17, 6172-6176.

Hohorst $H^{\cdot}$ L-(+)-Lactate. Determination with Lactate Dehydrogenase and NAD. In: Bergmeyer HU (ed.): Methods of Enzymatıc Analysıs (2 ed.) $1970,1425-1429$.

Jensen P, Barton-Gade PA: Performance and carcass characteristics of pigs with known genotypes for halothane susceptibility. In: Ludvigsen JB (ed.):
Stress susceptibility and meat quality in pigs, EAAP Publication no. 33, 1985, 80-87.

Jørgensen PF: Blood types and other biochemical markers for stresssusceptibility and meat quality in pigs. In: Frøysteın T, Slinde E \& Standal N (eds.): Porcine stress and meat quality, Norway: Agr. Food Res. Soc., 1981, 146-159.

Jørgensen PF: Electrolytes and the porcine stress syndrome. Some aspects of magnesium metabolism. Seventh Int. Conf. Prod. Dis. in Farm Animals, Cornell University, Ithacha, New York, July 25-27, 1989a, 70-73.

Jørgensen PF: Environmental influence on stress susceptibility in prgs. Acta anaesth. scand., 1989b, 33, suppl. 91, 55-57.

Knudson CM, Mickelson JR, Louis CF, Campbell $K P$ : Distınct immunopeptide maps of the sarcoplasmic retıculum $\mathrm{Ca}^{2+}$ release channel in malignant hyperthermia. J. B1ol. Chem., 1990, 265, 2421-2424.

Lamprecht W, Stein P, Heinz F, Welsser H. Creatine Phosphate. Determination with creatıne kinase, hexokinase and glucose-6-phosphate dehydrogenase. In: Bergmeyer HU (ed.): Methods of Enzymatic Analysis. 1974, 1777-1781.

Lamprecht W, Trautschold I- Procedure. Collection, treatment and stability of sample. In: Bergmeyer HU (ed.): Methods of Enzymatic Analysis, 1974, 2104-2108.

Lister D, Ratcliff $P W$ : The effect of the pre-slaughter injection of magnesium sulphate on glycolysis and meat quality in the pig. Proc. 2nd Int. Symp. Condition Meat Quality Pigs, Zeıst, Pudoc, Wageningen, Holland, 1971, 139-144.

Mickelson JR, Gallant EM, Rempel WE, Johnson KM, Litterer LA, Jacobson BA, Louls CF. Effects of the halothane-sensitivity gene on sarcoplasmic reticulum function. Amer J. Physiol., 1989, 257, C787-C794.

Moesgaard B, Quistorff B, Christensen VG, Terkelsen I, Jørgensen PF: Differences of post mortem ATP turnover in skeletal muscle of normal and heterozygote malignant hyperthermia pigs; Comparison of ${ }^{31} \mathrm{P}-\mathrm{NMR}$ and analytical biochemical measurements. Meat Sci., 1994, (subm. for publ.).

Quistorff B, Poulsen H: Evaluation of a freezeclamping technique designed for two- and threedımensional metabolic studies of rat liver in vivo. Quenching efficiency and effect of clamping on tıssue morphology. Anal. Biochem., 1980, 108, 249-256. 
Quistorff B, Johansen L, Sahlin K: Absence of phosphocreatine resynthesis in human calf muscle during ischaemic recovery. Biochem. J. 1993, 291, 681-686.

Reinhart RA: Magnesium metabolism. A review with special reference to the relationship between intracellular content and serum levels. Arch. Intern Med., 1988, 148, 2415-2420.

Sair RA, Lister D, Moody WG, Cassens RG, Hoekstra WG, Briskey EJ: Action of curare and magnesium on striated muscle of stress-susceptible pigs. Amer. J. Physiol., 1970, 218, 108-114.

Taylor DJ, Bore PJ, Styles P, Gadian DG, Radda GK: Bioenergetics of intact human muscle. $A^{31} P$ nuclear magnetic resonance study. Mol. Biol. Med., 1983, 1, 77-94.

Webb AJ: The halothane sensitivity test. In: Frøystein T, Slinde E \& Standal N (eds.): Porcine stress and meat quality, Norway: Agric. Food. Res. Soc., 1981, 105-124.

Webb AJ, Southwood OI, Simpson SP: The halothane test in improving meat quality. In: Tarrant PV, Eikelenboom G, Monin G (eds.): Evaluation and control of meat quality in pigs, 1987, 297315 .

\section{Sammendrag}

Effekt af magnesium tilskud på post mortem glykolysen $i$ skeletmuskulaturen hos svin. Et non-invasivt studium under anvendelse af ${ }^{31} P$-NMR spektroskopi.

Effekten af magnesiumtılskud på det postmortelle glykolytiske forl $\varnothing \mathrm{b} i$ heterozygote malign hyperthermifølsomme grise blev unders $\varnothing$ gt, efter at grisene havde været udsat for en kombination af halothan-anæstesi og succinylcholin injiceret intravenøst. Grisene blev halothan-anæsteseret og umiddelbart efter initiering af den depolariserende neuromuskulære blokerende virkning af succinylcholin, blev dyrene aflivet med en boltpistol. Faldet i niveauet af $\mathrm{PCr}$, som er en afspejling af omsætningen af ATP, blev fulgt i $m$. biceps femoris 40-70 minutter post mortem under anvendelse af ${ }^{31} \mathrm{P}$-NMR spektroskopi. I 3 ud af 4 eksperimenter (hvert bestående af en kontrolgris og en gris, der havde fået magnesium tilskud i 3 dage) blev der fundet en signifikant langsommere nedbrydning af $\mathrm{PCr}$ hos grisen, der havde fået magnesium. Dette afspejler et langsommere ATP forbrug hos disse grise, og dermed en reduceret hastighed af glykolysen. På trods af nogle individuelle variationer er konklusionen, at de grise, som er i stand til at mobilisere magnesium i relation til stress-situationer, bedre kan modstå stress-faktorerne. Variabiliteten kan skyldes, at skeletmuskulaturen hos de yngste grise var utilstrækkelig udviklet til at udtrykke malign hyperthermifølsomhed.

(Received July 6, 1993; accepted August 30, 1993).

Reprints may be requested from: P. Fogd Jørgensen, Department of Anatomy and Physiology, The Royal Veterinary and Agricultural University, Bülowsvej 13, DK-1870 Frederiksberg C, Denmark. 